\title{
Autoinducer-2 Signaling: Modulates Cell-Cell Quorum Sensing in Oral Biofilm
}

\section{Rajiv Saini*}

Department of Periodontology and Oral Implantology, Pravara Institute of Medical Sciences, Loni, Maharashtra, India

The principle of considering dental plaque as biofilm had emerged in the last 10-15 years that totally changes the concept of pathogenesis and control of periodontal diseases. A biofilm environment confers certain properties to bacteria that are not seen in the nomadic state, a fact that explains the importance of recognizing dental plaque as a biofilm and not as bacteria in the planktonic state [1]. Some of the unique properties of biofilm are dependent on the ability of the bacteria and micro-colonies within the biofilm to communicate with one another. Bacteria also harbor vast arrays of mechanisms to sense and respond to features of their environment, including the presence of other bacteria. Small diffusible molecules known as autoinducers are synthesized and released in accordance with cell number; their subsequent detection enables bacteria to synchronously regulate behaviors at the population level in a process known as quorum sensing [2].

Quorum sensing systems in bacteria have been generally divided into at least three classes:

a) LuxI/LuxR-type quorum sensing in Gram-negative bacteria, which use acyl-homoserine lactones (AHL) as signal molecules

b) Oligopeptide two-component-type quorum sensing in Grampositive bacteria, which use small peptides as signal molecules

c) LuxS-encoded autoinducer-2 (AI-2) quorum sensing in both Gram-negative and Gram-positive bacteria

Each type of signal molecule is detected and responded by a precise sensing apparatus and regulatory network [3-8]. Many quorum sensing signals are species specific; however, production of and responses to one molecule, autoinducer-2 (AI-2), are observed throughout the bacterial kingdom and AI- 2 produced by one species can influence gene expression in another, this signal can foster interspecies communication and enable bacteria to modify behaviors such as virulence, luminescence, and biofilm formation across different species [9].

Dental plaque will be a center point production of quorum-sensing signal molecules, due to the intricacy of the biofilm organization and the existence of putative pathogens which could lead to develop periodontal diseases. As Fusobacterium nucleatum is the major coaggregation bridge organism that links early colonizing commensals and late pathogenic colonizers in dental biofilms via the accretion of periodontopathogens, it is proved that AI-2 of $F$. nucleatum contributes to this interspecies interaction, and interruption of this signaling could result in the inhibition of biofilm formation of periodontopathogens [10].

Research on microbial biofilms is being made in many dimensions, with specific focus on elucidation of the genes specifically expressed by biofilm-associated organisms, assessment of different control approaches for either preventing or remediating biofilm colonization of medical devices, and development of new methods for evaluating the efficacy of these treatments [11]. The central goal is to develop Antiquorum-sensing strategies to combat periodontal diseases.

\section{References}

1. Tatakis DN, Kumar PS (2005) Etiology and pathogenesis of periodontal disease. Dent Clin North Am 49: 491-516.

2. Rutherford ST, Bassler BL (2012) Bacterial quorum sensing: its role in virulence and possibilities for its control. Cold Spring Harb Perspect Med 2: a012427.

3. Miller MB, Bassler BL (2001) Quorum sensing in bacteria. Annu Rev Microbiol 55: 165-199.

4. Waters CM, Bassler BL (2005) Quorum sensing: cell-to-cell communication in bacteria. Annu Rev Cell Dev Biol 21: 319-346.

5. Van Bodman SB, Willey JM, Diggle SP (2008) Cell-cell communication in bacteria: United we stand. J Bacteriol 190: 4377-4391.

6. Dunny GM, Leonard B (1997) Cell-cell communication in Gram-positive bacteria. Annu Rev Microbiol 51: 527-564.

7. Federle MJ, Bassler BL (2003) Interspecies communication in bacteria. J Clin Invest 112: 1291-1299.

8. Schauder S, Bassler BL (2001) The languages of bacteria. Genes Dev 15 1468-1480.

9. Thompson JA, Oliveira RA, Djukovic A, Ubeda C, Xavier KB (2015) Manipulation of the quorum sensing signal Al-2 affects the antibiotic-treated gut microbiota. Cell Rep 10: 1861-1871.

10. Jang YJ, Choi YJ, Lee SH, Jun HK, Choi BK (2013) Autoinducer 2 of Fusobacterium nucleatum as a target molecule to inhibit biofilm formation of periodontopathogens. Arch Oral Biol 58: 17-27.

11. Saini R, Saini S, Sharma S (2011) Biofilm: A dental microbial infection. J Nat Sci Biol Med 2: 71-75.
*Corresponding author: Dr. Rajiv Saini, Associate Professor, Department of Periodontology \& Oral Implantology, Pravara Institute of Medical Sciences, Loni, Ahmednagar, Maharashtra-413736, India, Tel: +91 9923206789; E-mail: drperiodontist@yahoo.co.in

Received January 23, 2016; Accepted January 26, 2016; Published February 03, 2016

Citation: Saini R (2016) Autoinducer-2 Signaling: Modulates Cell-Cell Quorum Sensing in Oral Biofilm. Dentistry 6: e116. doi:10.4172/2161-1122.1000e116

Copyright: @ 2016 Saini R. This is an open-access article distributed under the terms of the Creative Commons Attribution License, which permits unrestricted use, distribution, and reproduction in any medium, provided the original author and source are credited. 